\title{
COVID-19 AND DENTISTRY - SAFETY ISSUES REGARDING DOCTOR AND PATIENT SITUATION IN TIME OF VACCINE AVAILABILITY
}

\author{
Patrycja Pietrzak ${ }^{1}$, Wojciech Hanke ${ }^{2}$ \\ ${ }^{1}$ Medical University of Lodz, Łódź, Poland \\ Department of Orthodontics \\ ${ }^{2}$ Nofer Institute of Occupational Medicine, Łódź, Poland \\ Department of Environmental Epidemiology
}

\begin{abstract}
Since one of the main mode of the COVID-19 transmission is through close contact with the infected person $(<1.5 \mathrm{~m}$ distance $)$ and body fluids (saliva, blood, aerosol particles), the dentists have become one of the groups being at most risk of being infected. The aim of this article is to present, based on the research search (publications from the last year 2020 and from the beginning of the current year 2021), the general overview of the situation during the COVID-19 pandemic with regard to patients and dentist as well as supporting personal protection. Authors identified 7 questions related to this topic. They address among others such issues as identification of the COVID-19 patients coming to the dental practice; protection of both the dentist and the patient from infection and a need for guidelines on the scope of emergency dental services during the pandemic. Opinions on the subject, expressed by the experts in the field, including general guidelines were also taken into consideration. In general, based on the literature overview, the COVID-19 pandemic has completely transformed the healthcare system, including dentistry. The identification of the COVID-19 patients coming to the dental practice has become a necessity (including taking epidemiological survey, temperature measurement). Currently, since "the group zero" in significant part has completed the full vaccination process, the health personnel (including dentists) might feel safer. The efficacy of the vaccines is high and provides a certain sense of security. Med Pr. 2021;72(6):729-37
\end{abstract}

Key words: COVID-19, infection, prevention, epidemiology, dentistry, vaccine

Corresponding author: Patrycja Pietrzak, Medical University of Lodz, Department of Orthodontics, al. Kościuszki 4, 90-419 Łódź, Poland, e-mail: patrycja.pietrzak@umed.lodz.pl

Received: April 20, 2021, accepted: June 15, 2021

\section{INTRODUCTION}

Acute respiratory coronavirus 2 (SARS-CoV-2), being the source of the COVID-19 infection, remains one of the most crucial issues to be addressed in public health. As response to the pandemic the access to dental services has been limited, in the majority of cases only to emergency procedures. According to the American Dental Association Health Policy Institute the $76 \%$ of dentists that completed the survey on March 27, 2020 declared that their practices remained open but only to emergency patients and 19\% of dentists reported that they had completely closed down their offices [1]. Since then, many dental practices have opened up again under strict sanitary regime, nevertheless the fear of infection remains omnipresent. The situation is subject to change and therefore, both the problems and the proposed solutions may vary dependent on the individual situation of each country as far the organization of medical system and financial resources are concerned.
The aim of this article is to present, based on the research search, the overview of the situation during the COVID-19 pandemic with regard to patients and dentist as well as dentist supporting personal protection. The authors identified 7 questions related to this topic. They address among others such issues as identification of the COVID-19 patients coming to the dental practice; protection of both the dentist and the patient from infection and a need for guidelines on the scope of emergency dental services during the pandemic.

Taking into account that most countries have implemented the anty-COVID-19 vaccination programmes, the authors also searched for information about the possibility of infection in time when a significant part of medical personnel and patients has already been vaccinated.

\section{METHODS}

Analysis of the literature (both English and in Polish language) on topics related to COVID-19 and dentistry, 
published during the last year (2020) and the beginning of the current year (2021) was done using Pubmed and PMC search engine. The choice of literature was done on the basis of the general narrative revision. The inclusion criteria included: the relevance of the article in relation to the COVID-19 pandemic and the date of publication. Keywords such as "COVID-19," "dental practice," "dentistry," "infection" were used during the search. The opinions on the subject, expressed by the experts in the field, including general guidelines were also taken into consideration.

\section{HOW TO IDENTIFY THE COVID-19 PATIENTS COMING TO THE DENTAL PRACTICE IN BOTH EFFICIENT AND NON-STIGMATIZING MANNER?}

Initial patient screening involving the evaluation, regarding the necessity of dental procedures is recommended. During such an evaluation the following matters should be taken into consideration: risk involving COVID-19 infection and general health status assessment with regard to the dental condition:

- emergency care classification: patients with dental condition that may impede swallowing, breathing or result in an uncontrolled bleeding);

u urgent/emergent care: patients with dental condition that is characterized by the consistent presence of an infection/pain or with dental condition that may be a potential reason for immediate intervention);

- elective care: patients who need general dental procedures that do not impede basic function or involve pain symptoms.

Patients can be classified into the following groups [2]:

first group: clinically healthy with no potential infection (asymptomatic),

- second group: patients suspected of being asymptomatic carriers - these group involves history of travelling and contact with positive COVID-19 individuals,

third group: patients who have confirmed or suspected COVID-19 infection.

In order to both maintain and secure the dental practice during the pandemic, the guidelines concerning patients registration and further proceedings have been published by Polish Dental Association (Polskie Towarzystwo Stomatologiczne - PTS) in March 2020 [3]. First step is the patient's registration. This procedure should be done by telephone in order to avoid personal contact. During remote medical consultations medical history should be taken, including information concerning staying abroad during the last 14 days.

In cases with dyspnea, flu-like symptoms (cough, increased body temperature, cold, runny nose) expressed by the patient during the tele-consultation, the appointment should be postponed. Such action is also recommended in cases with planned appointments if they belong to the increased risk group (coexistent chronic diseases: diabetes, heart diseases, immunodeficiency) or are $\geq 65$ years old. Each medical facility should have a specially selected area or a room at the entrance where the patient's temperature and epidemiological survey should be taken.

In case the patient is a minor, then it is recommended that he/she is accompanied only by one parent/legal guardian. In exceptional cases such as a disabled person or a medical assistance from the hospital, more than 1 person accompanying the patient can enter the facility. Nevertheless, it is worth noting that not only patients but the parents/guardians must undergo the same sanitary procedure (hand disinfection upon entering the facility, measurement of body temperature, obligatory epidemiological survey). The distance between patients in queue should be 1-2 $\mathrm{m}$. If the epidemiological survey is negative and no symptoms of infection have been diagnosed, then further procedures depend on the result of body temperature measurement. In case of an emergency with body temperature $<37.3^{\circ} \mathrm{C}$ or $>37.3^{\circ} \mathrm{C}$ but $<37.9^{\circ} \mathrm{C}$, the stationary visit is recommended. In case there are flu-like symptoms; the body temperature is $>37.3^{\circ} \mathrm{C}$ but $<37.9^{\circ} \mathrm{C}$ and the patient is in a emergency state regarding the medical procedure then the further course of action is being decided by the doctor being in charge of treatment. Finally if the patient is in a emergency state and the body temperature is $>37.9^{\circ} \mathrm{C}$, then one should inform the Sanitary-Epidemiological Station and proceed in accordance with the instructions given, including transferring the patient to the local isolation ward in a hospital. The general outline concerning this issue is presented in Table 1.

\section{WHAT ARE THE MOST FREQUENT MODES OF COVID-19 INFECTION TRANSMISSION?}

COVID-19 can be transmitted through droplets, which is considered to be the main mode of transmission. Large droplets (size $\geq 5-10 \mu \mathrm{m}$ ) are reported to be carriers of virus particles. Such mode of transmission can take place in case a person comes in close contact with an infected 
Table 1. Patient's admittance system with regard to the body temperature [3]

\begin{tabular}{ll}
\hline \multicolumn{1}{c}{ Body temperature } & \multicolumn{1}{c}{ Course of action } \\
\hline$<37.3^{\circ} \mathrm{C}$ or $>37.3^{\circ} \mathrm{C}$ but $<37.9^{\circ} \mathrm{C}$ & stationary visit recommended \\
$>37.3^{\circ} \mathrm{C}$ but $<37.9^{\circ} \mathrm{C}$ with flu-like symptoms, emergency state & decided by the doctor being in charge of treatment \\
$>37.9^{\circ} \mathrm{C}$ with flu-like symptoms, emergency state & $\begin{array}{l}\text { information given to the Sanitary-Epidemiological Station; } \\
\text { further proceedings depend on the instructions given, } \\
\text { including transferring the patient to the local isolation ward in a hospital }\end{array}$ \\
\hline
\end{tabular}

symptomatic patient (e.g., signs of sneezing or coughing). Close contact means that the distance range from the infected person is $1.5 \mathrm{~m}$ [4]. SARS-CoV-2 transmission can occur through both core droplets (suspension in aerosol through sneezing, coughing).

Flugge microdroplets, in case of direct proximity transmission: $>15 \mathrm{~min}$ and distance $<2 \mathrm{~m}$, and fomite mode of transmission. A fomite refers to inanimate objects that can carry and spread disease and infectious agents. Fomites can also be called passive vectors. Period of incubation involving contact with saliva droplets through direct mucous contact: ingestion is 5-14 days [5].

Another frequently mentioned mode of transmission is the airborne one. This particular mode of transmission involves aerosols $(<100 \mu \mathrm{m}$ in diameter). They can be created through such simple actions like talking, sneezing or coughing. What makes this mode of transmission so dangerous is the fact that such aerosol can be suspended in the air [6].

It has been documented that aerosol from virulent pathogens like coronavirus can be spread at a distance of $>1.83 \mathrm{~m}$. Source of aerosol formation can also originate from medical procedures such as bronchoscopy and mechanical ventilation. In dental practice such aerosol transmission is highly likely to occur due to frequent application of such devices as high-speed dental handpiece with running water (endodontic treatment, conservative dentistry treatment, periodontic treatment, prosthodontic treatment, etc). The aerosol can mix with patient's saliva and blood. COVID-19 transmission can be described as direct or indirect.

Direct forms of transmission involve aerosol during dental and surgical procedures, droplet transmission, contact with secretions and body fluids such as: tears, semen, urine, saliva, feces as well as transmission from mother to child. Indirect forms of transmission, on the other hand, involve objects which came into contact with an infected person (e.g., thermometer), and surface of fomite contact (fixture, furniture) [6]. It is worth noting that SARS-CoV-2 virus is able to survive $>72 \mathrm{~h}$ on stainless steel, plastic surfaces and $\leq 24 \mathrm{~h}$ on cardboard surfaces, which further increases the risk of infection [7] It was also reported that the longevity of the virus varies depending on the type of the surface in question $(\leq 8 \mathrm{~h}$ on latex gloves, $\leq 2 \mathrm{~h}$ on medical aprons in comparison with 4-5 days on paper or 2-3 days on steel) [8].

\section{HOW TO PROTECT HEALTHCARE WORKERS (INCLUDING DENTISTS) AND PATIENTS FROM INFECTION?}

Since the beginning of the pandemic outbreak the number of people infected by coronavirus have increased dramatically to more than 23 million in 213 nations and territories in only 10 month time. Death rate is also reported to be relatively high (approx. 0.9 milion deaths worldwide) [9]. Currently, as of the April 20, 2021, the number of people infected has increased to 143137301 (in Poland - 2704 571) with number of deaths reaching 3049115 (in Poland - 62 734) [10].

Therefore, the matter regarding protection of both patients and Health Care Workers (including dental practitioners) has become a burning and crucial issue. Several measures were proposed at both patient's and dentist's office level.

\section{Patient's protection level}

One of recommended prevention for the patient is to use mouth rinses before the start of a dental appointment. The main protective aspect of using mouthwashes is their oxidative effect, decreasing the salivary load of the virus. The recommended course of the action is the application of $0.05-0.1 \%$ solution of cetylpyridinium chloride (CPC), $0.2 \%$ solution of povidone or $1 \%$ hydrogen peroxide. COVID-19 is susceptible to oxidation, the mouth rinse involving the application of hydrogen peroxide is especially recommended as means of protection against the infection [11]. Nevertheless in a recent study by Ather et al. [12], further conclusions concerning the effectiveness of mouthrinses against SARS-CoV-2 were pointed out. The following mouthrinses have been taken into consideration as far 
as the effectiveness was concerned: chlorhexidine, hydrogen peroxide, povidone iodine, quaternary ammonium compounds and essential oils. It was stated that based on the data from in vitro studies, the mouthrinses can play a positive role in reducing the viral load of SARS-CoV-2 (povidone iodine, though there should be more in vivo studies performed in order to give thorough clinical recommendations). The results for other type of mouthrinses, including quaternary ammonium compounds (Benzalkonium chloride and essential oils) also look positive as far as the reduction of viral load is concerned, however there is still not enough data published to draw general conclusions.

On the contrary, results concerning both chlorhexidine and hydrogen peroxide are not consistent as far as the effectiveness against SARS-CoV-2 is concerned (that concerns in vivo studies which are generally too few for the general recommendations to be given). In general, the authors of this article state that more in vivo studies need to be performed in order to fully assess the effectiveness of different types of mouthrinses against SARS-CoV-2 [12].

Second issue is handwashing. It is vital to have a touchless container with a disinfectant agent (for both shoes and hands separately if possible) mounted on the wall near the entrance to the dental office/clinic. The touchless mode reduces the risk of contamination since many people tend to use their thumb instead of their elbow to activate the container. Hand washing can be done by applying an antibacterial gel or soup with water for min. $20 \mathrm{~s}$. It has been reported that proper hand washing can reduce the transmission by $6-14 \%$ [11].

Patient's footwear can be disinfected with a bleach solution of $1 / 5$ of sodium hypochlorite and $4 / 5$ of water; $200 \mathrm{ml}$ sodium hypochlorite (at $10000 \mathrm{ppm}$, with a change every $4 \mathrm{~h}$ ) with $800 \mathrm{ml}$ of water. The issue, regarding handwashing performed by the patient both before and after dental care was raised in an article by Siles-Garcia et al. [11], but there is no data regarding the practical application of this rule into practice.

\section{Protection on the dentist's office level}

As it was reported, the longevity of the virus may increase when the humidity level is between 30 to 50\%, so it is crucial to have proper level of humidity present in the dental office [8]. Furthermore, each dental professional should be well equipped with an adequate set of the Protective Care Equipment including visor, disposable plastic apron, goggles, fluid-resistant surgical mask. Adequate air disinfection methods which can be useful in maintaining correct decontamination process are among others: application of HEPA fillers, UV-C flow germicidal lamps, fogging with hydrogen peroxide and plasma application [8].

\section{WHICH TYPE OF MASKS USED AS PROTECTIVE CARE EQUIPMENT ARE CONSIDERED BEING THE MOST RELIABLE?}

\section{Patient protection}

Types of masks that should be worn vary with regard to the transmission scenario; situation/settings and the general purpose of the mask as presented in the guidance outline by WHO on December 1, 2020 (Table 2). As far as the term "medical mask" is concerned - according to the WHO guideline a medical mask is a surgical or procedure mask that is pleated or flat [13].

\section{Dentist protection}

The choice of proper type of protective care equipment is crucial as far as protection against COVID-19 infection is concerned. The application of masks has been recommended by both WHO and Centers for Disease Control and Prevention (CDC). The masks have been classified into 2 types: surgical and respiratory. Both of them are disposable. The effectiveness regarding protection depends on both filtering capacity and the mask structure. The surgical mask are recommended for COVID-19 patients because they prevent the spread of microorganisms from the inside out. They are classified as type I, type II, type IIR (all of them bearing a official nomenclature EN 14683; 80\% filtration rate). Nevertheless these types of masks do not protect against particles spreading around their edges as the seal is not hermetic enough. Out of all the types the IIR type is considered to be the most effective. Other type of masks are referred to as being respiratory ones.

These can be classified as FFP1 (filtration capacity $80 \%)$, FFP2 (filtration capacity 95\%), FFP3 (filtration capacity 99\%). The filtration rate concern the particles with a diameter of $0.3 \mu$. The respiratory masks should be equipped with electrostatic charge and multiple layers of polypropylene. This makes the filtration of outgoing and incoming air possible. Other classification of respiratory masks involve the following aspects of protection: $\mathrm{R}$ and $\mathrm{P}$ types to be used in particular environments without and with oil, $\mathrm{N}$ types - to be used in particular environments and oil free aerosols.

The level of effectiveness regarding filtering capacity of $0.3 \mu$ particles can be divided into 3 groups: $95 \%$, 
Table 2. Type of the masks used by patients of medical institutions and their characteristics

\begin{tabular}{|c|c|c|c|c|}
\hline Transmission scenario & Target population & Setting & Activity & Mask type \\
\hline $\begin{array}{l}\text { Known or suspected } \\
\text { community or } \\
\text { cluster transmission } \\
\text { of SARS-CoV-2 }\end{array}$ & $\begin{array}{l}\text { other staff, patients, } \\
\text { visitors, service suppliers }\end{array}$ & $\begin{array}{l}\text { health facility (including primary, } \\
\text { secondary, tertiary care levels, } \\
\text { outpatient care, and long-term care } \\
\text { facilities) }\end{array}$ & $\begin{array}{l}\text { for any activity } \\
\text { or in any } \\
\text { common area }\end{array}$ & medical or fabric mask \\
\hline $\begin{array}{l}\text { Known or suspected } \\
\text { sporadic transmission } \\
\text { of SARS-CoV-2 cases }\end{array}$ & $\begin{array}{l}\text { other staff, patients, } \\
\text { visitors, service suppliers } \\
\text { and all others }\end{array}$ & $\begin{array}{l}\text { health facility (including primary, } \\
\text { secondary, tertiary care levels, } \\
\text { outpatient care, and long-term care } \\
\text { facilities) }\end{array}$ & $\begin{array}{l}\text { no routine } \\
\text { activities in } \\
\text { patient areas }\end{array}$ & $\begin{array}{l}\text { medical mask not required } \\
\text { medical mask should be worn } \\
\text { if in contact or within } 1 \text { m of patients, } \\
\text { or according to local risk assessment }\end{array}$ \\
\hline
\end{tabular}

$99 \%, 100 \%$. Out of these types of respiratory masks, the N95 type is considered to be a standard in the US. The lifespan of surgical masks is up to $4 \mathrm{~h}$ and FFP masks up to $8 \mathrm{~h}$ [14].

The recent study published by Tysiąc-Miśta et al. [8], the FFP respirators can protect an individual particle infiltration, which size is $\geq 0.3 \mu \mathrm{m}$. Since the size of the SARS-CoV-2 virus is $0.06-0.14 \mu \mathrm{m}$, the protection of the PPE masks can be regarded as insufficient [8]. It also worth mentioning that the prolonged application of protective care equipment may cause significant degree of skin irritation and other symptoms including: skin allergies, asthma, rhinitis, rash, laryngitis. Skin symptoms involving face were reported after prolonged application of N95 masks (35\% of cases); and on hands after wearing protective gloves (in 20\% of cases). Therefore each application of the protective care equipment should be done with caution [8].

\section{HOW TO DIFFERENTIATE BETWEEN DENTAL SERVICES THAT ARE ABSOLUTELY INDISPENSABLE DURING THE PANDEMIC AND THESE THAT DO NOT FALL INTO THIS CATEGORY?}

Differentiation between dental procedures that are absolutely necessary and these which are not is difficult from a patient's perspective. Patients, especially during the pandemic, during long periods of forced self-isolation might seek dental care not only in emergency cases but also to improve one's esthetics and self-esteem during these difficult times (bleeching, veneers, orthodontic treatment as means of esthetic improvement in mild crowding cases with no functional pathologies diagnosed).

In each country internal guidelines regarding the emergency of dental procedures have been published. In Poland such guidelines were published by PTS in March 2020.
As an example, in orthodontics the dental procedures were divided into the following categories: acute emergency cases (only patients with life threat situation or with the need for further diagnostics - orthodontic brackets must be removed before diagnostic procedures are undertaken: MRI or before placement of stabilizing posttraumatic splints) and planned orthodontic care.

Patients with planned orthodontic care were divided as follows:

new patients (these should not be taken in for treatment until the pandemic is cancelled with the exception of patients with pain symptoms and clefts); consultations of such patients should be done first and foremost by telephone;

patients with removable appliances (control visits every 8 months); patients treated with splints (new splints given for 8 weeks, if possible - 12 weeks; in case of damage or new steps being taken as far as further treatment is concerned, the last set of splints should be worn with the next appointment planned in 12 weeks time);

patients with fixed appliances (repairs regarding elements such as brackets can be done with utmost care; during these procedures aerosol formation should be avoided); patients with palatal fixed appliances like Biedermann appliance with Hyrax screw or wearing erbst of Headgear appliances - these appliances should not be activated; protection against irritation of oral mucosa should be maintained; impressions can be done but with cleaning and disinfection procedure being maintained;

- patients before and after orthognathic surgery (with interdisciplinary ortho-surgical treatment) should be treated; patients wearing retainers after orthodontic treatment: every control visits should be postponed for the next 3 months with the exception of repairs. In general, placement or removal of a fixed appliance (if the treatment has not been started yet) should be postponed for the next 12 weeks [15]). 
The guidelines regarding dentistry and the necessity of treatment have been updated by the Health Ministry on July 15,2020 . In general in the guidelines concerning the orthodontic treatment need the decision was left to the doctor being in charge of patient's treatment (to be done individually).

The health service concerning orthodontics should be divided into: emergency medical care and planned medical care. As far as the emergency medical care is concerned, the frequency of control appointments regarding both removable and fixed appliances during the pandemic can be reduced.

In case of an emergency (iatrogenic effect of orthodontic appliances, including the application of skeletal anchorage or other elements including fixed retainers) the medical assistance should be provided. In case of an active orthodontic treatment the necessity of control visits should be done individually (especially in cases with fixed appliances) taking into account the guidelines concerning the COVID-19 protection established in a given dental practice.

The planned orthodontic care should be postponed with the exception of the cases where the postponement would have resulted in worsening of the occlusal condition and also in cases concerning treatment of patients under Orthodontic Health Care Programme concerning patients with congenital malformations. In general, in all situations presented above, first contact should be done by telephone and the doctor should assess the necessity of patient's visit in person [16].

\section{WHAT IS THE EFFICACY OF THE COVID-19 VACCINES ?}

Three major vaccines that have come to the forefront as far as the prevention policy against SARS-CoV-2 infection is concerned are the ones developed by Pfizer, Moderna and AstraZeneca. The authorization for the emergency use application of the Pfizer vaccine was given on December 11, 2020 by the Food and Drug Administration (FDA) with the recommendation having being issued on December 12, 2020. The Pfizer vaccine was referred to as "the lipid nanoparticle-formulated nucleoside-modified mRNA vaccine" to be administered in people 16 years and older. Oliver et al. [17] reported that the results of the double-blind, placebo controlled clinical trial (involving $>43000$ participants with an age range between 16 and 91 years with a 2 month follow up) included the information concerning the efficacy level of the Pfizer vaccine being approx. 95\% $[13,17]$.
Another vaccine, which was developed against COVID-19 infection was the Moderna vaccine. The Moderna vaccine was authorized for an emergency application on December 18, 2020 by the FDA with the recommendation having been given on December 19 , 2020. The efficacy of this vaccine was reported by WHO to be similar to the efficacy of the Pfizer vaccine (92\% efficacy level 14 days after the first dose).

On the contrary to the Pfizer and Moderna vaccine, the third one (AstraZeneca) was reported by WHO to have the lowest level of efficacy against symptomatic COVID-19 infection (63.09\%) [18].

The question remained whether the viral transmission would be substantially reduced in individuals who have received the first dose of the vaccine. Such data would be useful in assessing the long-term benefits of the vaccine administration.

According to the research done by Levine-Tiefenbrun et al. [19], a 4-fold reduction of viral load was observed in positive SARS-CoV-2 test results in patients who have received the first dose of the Pfizer vaccine and were infected 12-28 days after the vaccination.

However it is worth noting, that this was an initial observational study and it's results might not mirror the situation in different types of population [19].

Similar conclusions concerning the reduction in viral load have been reached by Petter et al. [20] (reduction rate being estimated at $1.6 \times$ to $20 \times$ after vaccination) [20]. Furthermore, the efficacy of the Pfizer and Moderna vaccines against the new variants of the SARS-CoV-2 virus is also a matter of concern. It was reported that both Pfizer and Moderna are effective against the British variant of the coronavirus (B.1.1.7) and also provide a certain level of protection against the variant P1 found in Brasil (even though it was stated that both Moderna and Pfizer are 4-8 fold less effective). Nevertheless, the effectiveness of these vaccines as far as the South African variant is concerned is reported to be of lower value (Pfizer and Moderna vaccines: 6-8 fold less effective while AstraZeneca vaccine 86 times less effective) [21].

\section{IS THERE A POSSIBILITY THAT VACCINATED DENTISTRY PERSONNEL OR PATIENT MAYBE A SOURCE OF INFECTION?}

It was also reported that the members of the health personnel in the UK who were vaccinated with Pfizer vaccine were less likely to develop COVID-19 disease (effectiveness against SARS-CoV-2 infection having been reported as 86\%) [22]. However there still 
remain some doubts regarding their role in spreading of diseases. The term "fully vaccinated" in this case concerns people who are at least 2 weeks after having obtained the second dose of the Pfizer or Moderna vaccine or at least 2 weeks after having received the single dose of the Johnson and Johnson vaccine. It is strongly postulated that people who meet these requirements do not have to wear masks or maintain social distancing when visiting other fully vaccinated people indoors or who have not been vaccinated but are from the same household. Furthermore fully vaccinated people do not have to get tested for COVID-19 or undergo quarantine if they had a confirmed contact with an infected person/people who was/were asymptomatic. Nevertheless it was also stated that fully vaccinated people should still take the following precautions: wear adequate protective care equipment when being in public (masks) and maintain social distance. They should adhere to the same rules upon visiting people, who were not vaccinated (with a high risk of severe COVID-19 infection) or have an unvaccinated family member with a high risk of severe COVID-19 infection. Protective care equipment should also be worn upon visiting people from multiple households [23].

The issue that seems to be the most concerning right now is the fact whether fully vaccinated people can be the source of the virus transmission or not. The effectiveness of the vaccinations seems to be quite promising as far as the reduction of the COVID-19 infection is concerned. It was reported by CDC that people who received 2 doses of the Pfizer vaccine had a 4 -fold lower viral load than people who were not vaccinated (with the viral load being described as a factor linked to the transmission rate) [23].

According to Deborah Fuller [24], an epidemiologist from the Washington University School of Medicine, the vaccination will not completely reduce the risk of infection. That means that if the effectiveness rate is for instance $95 \%$, then the $5 \%$ of people who have received the vaccine might still become infected and express the COVID-19 symptoms but are less likely to be hospitalized. It was also stated that fully vaccinated people might still be asymptomatic carriers of infection. Nevertheless it was also reported that even if the transmission is still going to occur in such cases, the process of virus shedding (amount of virus coming from the mouth or the nose) will be significantly reduced as far as the fully vaccinated people are concerned. Recent research seems to be a confirmation of the vaccines' success in reducing both the amount of COVID-19 infection and transmission in fully vaccinated people. In a pre-print study by Hall et al. [25] on the effectiveness of the Pfizer vaccine among healthcare workers in England, it was stated that the infection number was higher in the unvaccinated group (977 new infections during 710587 person days follow up) than in the vaccinated group (71 new infections 21 days after the first dose; 9 new infections 7 days after the second dose). Among healthcare workers who were not vaccinated, the positive test percentage for COVID-19 was $0.8 \%$; among vaccinated personnel after less than 12 days after vaccination the positive test percentage was $0.37 \%$; among vaccinated personnel after more than 12 days after vaccination the percentage was even lower-being $0.2 \%$. Furthermore, it was stated that vaccinated healthcare personnel (12 days after having received the vaccine) is 4 times less likely to have an asymptomatic COVID-19 infection. In a study by Lipsitch et al. [26] it was reported that the transmission rate after the vaccination with the Moderna vaccine can be decreased by at least $61 \%$ after 1 dose. Furthermore it was recently reported in that the completion of the full vaccination process with Pfizer or Moderna vaccines increases the protection rate concerning the possibility of the infection. This reduction is especially visible 14 days or more after receiving the second dose (with only 7 out of 14990 fully vaccinated health care workers in California having the positive test for COVID-19 infection) [27].

In such case, the scenario can be seen as an optimistic one since the vaccines play a significant role in the reduction of both the number of infections and symptomatic cases, which is beneficial to public health $[25,26]$.

It is worth noting that the situation might improve when the majority of the medical personnel has completed the full vaccination process in group zero. According to the article in Polityka Zdrowotna [28], which was posted on March 5, 2021, approx. 15392 dentists in Poland have been vaccinated (approx. $40 \%$ of dentists who are currently practising) and approx. 64804 doctors (approx. $46 \%$ of doctors who are currently practising) $[28,29]$. However this number is still too low for population protection and taking into the consideration the amount of medical personnel that has contracted the virus so far (data from March 1, 2021: infection diagnosed in 2254 dentists and 22493 doctors; 9532 dentists and 81011 doctors underwent quarantine; 14 dentists and 106 doctors died) it becomes obvious that only the fully completed vaccination process in group zero will decrease the infection and transmission rate among medical personnel thus preventing the virus 
from spreading. This way the patients will feel safer and they can resume regular appointments, of course under strict sanitary regime [30].

Another important question is how long will the vaccines provide protection against the COVID-19 infection? Since, the fact that such a person can be an asymptomatic carrier of the virus (however on a lesser scale), cannot be completely exluded, then there is a need of awareness of the fact that probably the vaccination process will have to be repeated again after $2-3$ years [31].

\section{CONCLUSIONS}

In general, based on the literature overview, the COVID-19 pandemic has completely transformed the healthcare system, including dentistry. The identification of the COVID-19 patients coming to the dental practice has become a necessity (including taking epidemiological survey, temperature measurement). Further problems are generated by the time spent on acquiring and putting on the protective care equipment (with many practices having to create a supply of HEPA masks, not only common surgical ones). Disinfection protocol has to be maintained with patients, standing often in a long queue before the visit can actually begin. Guidelines that have been published on the emergency dental services and differentiation between them is a good step in trying to come up with a solution on how to limit stationary visits to the ones being really necessary.

Currently, since the group zero has in significant part completed the full vaccination process, the health personnel (including dentists) might feel safer. The efficacy of the vaccines is high and provides a certain sense of security, nevertheless one must not forget that the transmission of the COVID-19 infection is not automatically reduced to zero in fully vaccinated people. They can both become reinfected (though the infection is said to be mild and not life-threatening) and they can be the asymptomatic carriers. What the world and Poland needs know is the achievement of the population immunity. The society can slowly think about returning to our normal lives.

\section{REFERENCES}

1. Wessels R, McCorkle LM. Analysis of patient safety risk management call data during the COVID-19 pandemic. J Healthc Risk Manag. 2021;40(4):30-37. https://doi.org/ 10.1002/jhrm.21457.
2. Irfan F, Khan JA, Ali B, Aslam K, Hasan A, Ali A et al. Dental Care During COVID-19 Pandemic: Guidelines for Teaching Hospital OPDs. J Pak Dent Assoc Karachi 2020;29(Special Supp.):S43-52. https://doi.org/10.25301/ JPDA.29S.S43.

3. Polskie Towarzystwo Stomatologiczne [Internet]. PTS; 2020 [cited 2021 Apr 20]. COVID-19 a praca lekarza dentysty: wytyczne PTS uaktualnione. Available from: https://pts.net.pl/COVID-19-a-praca-lekarza-dentystywytyczne-pts-uaktualnione/.

4. Aldahlawi SA, Afifi IK. COVID-19 in Dental Practice: Transmission Risk, Infection Control Challenge, and Clinical Implications. Open Dent J. 2020;14:348-54. https://doi.org/10.2174/1874210602014010348.

5. Kochhar AS, Bhasin R, Kochhar GK, Dadlani H. COVID-19 Pandemic and Dental Practice. Int J Dent. 2020; 9(2020):8894794. https://doi.org/10.1155/2020/8894794.

6. Karia R, Gupta I, Khandait H, Yadav A, Yadav A. COVID-19 and it's modes of transmission. SN Compr Clin Med. 2020;1-4. https://doi.org/10.1007/s42399-02000498-4.

7. Jamal M, Shah M, Almarzooqi SH, Aber H, Khawaja S, El Abed R, et al. Overview of transnational recommendations for COVID-19 transmission control in dental care settings Oral Dis. 2021;27(3):655-64. https://doi.org/ 10.1111/odi.13431.

8. Tysiąc-Miśta M, Dubiel A, Brzoza K, Burek M, Pałkiewicz K. Air disinfection procedures in the dental office during the COVID-19 pandemic. Med Pr. 2021;72(1): 39-48. https://doi.org/10.13075/mp.5893.01005.

9. Sivaraman K, Chopra A, Narayana A, Radhakrishnan RA. A five-step risk management process for geriatric dental practice during SARS-CoV-2 pandemic. Gerodontology. 2021;38(1):17-26. https://doi.org/10.1111/ger.12499.

10. Worldometer [Internet]. Worldometer 2021; [cited 2021 Apr 20]. COVID-19 Coronavirus Pandemic. Available from: https://www.worldometers.info/coronavirus/?utm campaign $=$ homeAdUOA?Si.

11. Siles-Garcia AA, Alzamora-Cepeda AG, Atoche-Socola KJ, Peña-Soto C, Arriola-Guillén LE. Biosafety for Dental Patients During Dentistry Care After COVID-19: A Review of the Literature. Disaster Med Public Health Prep. 2020;14:1-6. https://doi.org/10.1017/dmp.2020.252.

12. Ather A, Parolia A, Ruparel NB. Efficacy of Mouth Rinses Against SARS-CoV-2: A Scoping Review. Front Dent Med. 2021;2:648547.https://doi.org/10.3389/fdmed.2021.648547.

13. World Health Organization [Internet]. WHO; 2020 [cited 2021 Apr 20]. Mask use in the context of COVID-19: Interim guidance. Available from: https://apps.who.int/ iris/handle/10665/337199. 
14. Arellano-Cotrina JJ, Marengo-Coronel N, AtocheSocola KJ, Peña-Soto C, Arriola-Guillén LE. Effectiveness and Recommendations for the use of dental masks in the prevention of COVID-19. Disaster Med Public Health Prep. 2020;17:1-6. https://doi.org/10.1017/dmp.2020.255.

15. Polskie Towarzystwo Stomatologiczne [Internet]. PTS; 2020 [cited 2021 Apr 20]. Zasady ortodontycznego leczenia pacjentów na czas pandemii COVID-19. Available from: https://pts.net.pl/zasady-ortodontycznego-leczeniapacjentow-na-czas-pandemii-COVID-19/.

16. Infodent [Internet]. Infodent; 2020 [cited 2021 Apr 20]. Koronawirus: w końcu są wyczekiwane zalecenia $\mathrm{MZ}$ w stomatologii. Available from: https://www.infodent24. pl/lexdentpost/koronawirus-w-koncu-sa-wyczekiwavnezalecenia-mz-wstomatologii,115575.html.

17. Oliver S, Gargano J, Marin M, Wallace M, Curran K, Chamberland $\mathrm{M}$, et al. The Advisory Committee on Immunization Practices' Interim Recommendation for Use of Pfizer-BioNTech COVID-19 Vaccine - United States, December 2020. MMWR Morb Mortal Wkly Rep. 2020; 69:1922-4. http://dx.doi.org/10.15585/mmwr.mm6950e2.

18. World Health Organization [Internet]. WHO;2021 [cited 2021 Apr 16] The Oxford/AstraZeneca COVID-19 vaccine: what you need to know. Available from: https://www. who.int/news-room/feature-stories/detail/the-oxford-as trazeneca-COVID-19-vaccine-what-you-need-to-know.

19. Levine-Tiefenbrun M, Yelin I, Katz R, Herzel E, Golan Z, Schreiber L, et al. Decreased SARS-CoV-2 viral load following vaccination. medRxiv. Forthcoming 2021.

20. Petter E, Mor O, Zuckerman N, Oz-Levi D, Younger A, Aran D, et al. Initial real world evidence for lower viral load of individuals who have been vaccinated by BNT162b2. medRxiv. Forthcoming 2021.

21. Medscape [Internet]. Medscape; 2021 [cited 2021 Apr 20]. Where Do COVID Vaccines Stand Against the Variants? Available from: https://www.medscape.com/viewarticle/ 948335? src=wnl_edit_tpal\&uac=73796MK\&impID=328 $1482 \& f a f=1$

22. WBTV [Internet]. WBTV; 2021 [cited 2021 Apr 20]. Vaccine Team: Can a fully vaccinated person still transmit COVID-19 to an unvaccinated person? Available from: https://www.wbtv.com/2021/03/17/vaccine-team-can-ful ly-vaccinated-person-still-transmit-covid-an-unvaccina ted-person/.
23. Centres for Disease Control and Prevention [Internet]. CDC 2021 [cited 2021 Apr 20] Interim Public Health Recommendations for Fully Vaccinated People. Available from: https://www.cdc.gov/coronavirus/2019-ncov/vacci nes/fully-vaccinated-guidance.html.

24. Theconversation [ Internet]. The Conversation; 2021 [ cited 2021 Apr 20] Can vaccinated people still spread coronavirus? Available from: https://theconversation.com/ can-vaccinated-people-still-spread-the-coronavirus-155 095.

25. Hall V, Foulkes S, Saei A, Andrews N, Oguti B, Charlett A, et al. Effectiveness of BNT162b2 mRNA vaccine against infection and COVID-19 vaccine coverage in healthcare workers in England, Multicentre Prospective Cohort Study (The SIREN Study). Lancet. Forthcoming 2021

26. Lipsitch M, Kahn R. Interpreting vaccine efficacy trial results for infection and transmission. medRxiv. Forthcoming 2021.

27. Keehner J, Horton LE, Pfeffer MA, Longhurst CA, Schooley RT, Currier JS, et al. SARS-CoV-2 infection after vaccination in health care workers in California. N Engl J Med. Forthcoming 2021.

28. Polityka Zdrowotna [Internet]. Polityka Zdrowotna; 2021 [cited 2021 Apr 20]. Młodzi lekarze chcą się szczepić przeciw COVID-19. Available from: https://www.polity kazdrowotna.com/68573,mlodzi-lekarze-chca-sie-szcze pic-przeciw-COVID-19.

29. Medonet [Internet]. Medonet; 2021 [cited 2021 Apr 20]. Ilu lekarzy faktycznie jest już zaszczepionych? Informacje MZ wprowadzały w błąd opinię publiczną. Available from: https://www.medonet.pl/porozmawiajmyoszczepionce/ szczepionka-na-COVID-19,szczepienia-na-COVID-19-ilu-lekarzy-jest-juz-zaszczepionych--sprzeczne-dane,arty kul,41949295.

30. Cowzdrowiu [Internet]. Cowzdrowiu; 2021 [cited 2021 Apr 20]. Dane resortu zdrowia o zakażeniach i kwarantannie wśród medyków. Available from: https://cowzdro wiu.pl/aktualnosci/post/dane-resortu-zdrowia-o-zakaze niach-i-kwarantannie-wsrod-medykow.

31. Medexpress [Internet]. Medexpress; 2021 [cited 2021 Apr 20]. Czy osoby zaszczepione przeciw COVID-19 moga zarażać innych? Available from: https://www.medexpress. pl/czy-osoby-zaszczepione-przeciw-COVID-19-moga-za razac-innych/80462.

This work is available in Open Access model and licensed under a Creative Commons Attribution-NonCommercial 3.0 Poland License - http://creativecommons.org/licenses/by-nc/3.0/pl/deed.en. 